\title{
KARAKTERISTIK DEMAM BERDARAH DENGUE PADA ANAK DI RUMAH SAKIT UMUM ROYAL PRIMA MEDAN
}

\author{
Antje Irmella Tarigan, Rico Alexandre*, Oliviti Natali \\ Fakultas Kedokteran Universitas Prima Indonesia \\ *Korespondensi: rcortho11@gmail.com
}

\begin{abstract}
ABSTRAK
Penyakit DBD merupakan penyakit menular yang terutama menyerang anak-anak. Tujuan penelitian ini adalah untuk mengetahui distribusi proporsi pasien DBD pada anak berdasarkan umur, jenis kelamin, gejala klinis, diagnosis (pemeriksaan fisik dan pemeriksaan penunjang). Penelitian ini merupakan penelitian deskriptif dengan desain studi kasus. Data yang menjadi populasi dalam penelitian ini adalah seluruh data rekam medis pasien demam berdarah dengue pada anak di Rumah Sakit Umum Royal Prima Medan. Besar sampel sesuai dengan tujuan penelitian untuk mencari proporsi, maka sampel dibutuhkan minimal 100 data rekam medis pasien DBD pada anak. Teknik pengambilan sampel akan dilakukan dengan cara purposive sampling yaitu dipilih rekam medis yang paling lengkap datanya. Penelitian ini menyimpulkan pasien DBD anak terbanyak pada kelompok umur 15-19 tahun (29\%) dan berdasarkan jenis kelamin yang terbanyak laki-laki (59\%). Keluhan utama semua pasien adalah demam tinggi dan keluhan tambahan paling banyak adalah mual + muntah + ruam + nyeri kepala + $(23 \%)$. Hasil pemeriksaan fisik menunjukkan pasien yang diinspeksi terbanyak mengalami ruam (40\%). Pada pemeriksaan palpasi, perkusi, dan auskultasi menunjukkan semua pasien memiliki gejala soepel, timpani, dan suara paru normal/vesikuler. Berdasarkan uji Tourniquet yang terbanyak adalah positif, pemeriksaan hemoglobin yang terbanyak adalah normal (89\%), pemeriksaan hematokrit yang terbanyak adalah tidak normal $(89 \%)$ dan pemeriksaan leukosit yang terbanyak adalah tidak normal (89\%). Pada pemeriksaan trombosit menunjukkan semua pasien mengalami trombositopenia.
\end{abstract}

Kata kunci: demam berdarah dengue, anak

\begin{abstract}
Dengue Hemorrhagic Fever (DHF) is an infectious disease that mainly affects children. The purpose of this study was to determine the distribution of the proportion of DHF patients in children based on age, gender, clinical symptoms, diagnosis (physical examination and investigations). This research is a descriptive research with a case study design. The data that became the population in this study were all medical records of patients with dengue hemorrhagic fever in children at the Royal Prima General Hospital, Medan. The sample size is in accordance with the purpose of the study to find proportions, so a sample of at least 100 medical records of DHF patients in children is needed. The sampling technique will be carried out by purposive sampling, which is the medical record with the most complete data. This study concluded that the highest number of pediatric DHF patients was in the age group 15-19 years (29\%) and by gender the majority were male (59\%). The main complaint of all patients was high fever and the most additional complaints were nausea + vomiting + rash + headache $+(23 \%)$. The results of the physical examination showed that most of the patients inspected had rashes (40\%). On palpation, percussion, and auscultation, all patients had symptoms of soepel, tympanic, and normal/vesicular lung sounds. Based on the Tourniquet test the most were positive, the most hemoglobin examination was normal (89\%), the most hematocrit examination was abnormal (89\%) and the most leukocyte examination was abnormal (89\%). On examination of platelets showed all patients had thrombocytopenia.
\end{abstract}

Keywords: dengue hemorrhagic fever, children

\section{PENDAHULUAN}

Dengue adalah penyakit virus nyamuk yang telah menyebar dengan cepat di seluruh dunia dalam beberapa tahun terakhir.Virus dengue ditularkan oleh nyamuk betina terutama dari spesies Aedes aegypti. Demam dengue (DD) dan demam berdarah dengue (DBD) adalah penyakit infeksi yang disebabkan oleh virus dengue dengan manifestasi klinis demam, nyeri otot dan/atau nyeri sendi yang disertai leucopenia, ruam, limfadenopati, trombositopenia dan diatesis hemoragik. Penyakit ini bersifat musiman yaitu biasanya terjadi pada peralihan musim hujan ke musim kemarau yang memungkinkan vektor 
penular hidup di genangan air bersih. Penyakit ini juga menjadi masalah kesehatan masyarakat di Indonesia karena prevalensinya yang tinggi dan penyebarannya yang semakin luas. Penyebab adanya kasus, semakin meningkatnya jumlah kasus, dan bertambahnya wilayah terjangkit di Indonesia sangat kompleks dan multifaktorial dikarenakan semakin padatnya penduduk, transportasi lancar dari suatu daerah ke daerah lainnya, adanya pemukiman baru, faktor musim dan penyimpangan pola hujan, perilaku masyarakat menyimpan air secara tradisional, vektor nyamuk Aedes terdapat di seluruh pelosok tanah air khususnya di perkotaan, kurangnya partisipasi masyarakat dalam pemberantasan sarang nyamuk (PSN), serta adanya empat serotipe virus DEN yang bersirkulasi sepanjang tahun. ${ }^{3,4}$

Infeksi dengan salah satu serotipe akan menimbulkan antibodi seumur hidup terhadap serotipe yang bersangkutan tetapi tidak ada perlindungan terhadap serotipe yang lain. Seseorang yang tinggal di daerah endemis dengue dapat terinfeksi dengan 3 atau bahkan 4 serotipe selama hidupnya.Keempat jenis serotipe virus dapat ditemukan di berbagai daerah di Indonesia. ${ }^{4}$ Penyakit demam berdarah dengue (DBD) merupakan salah satu masalah kesehatan masyarakat di Indonesia yang jumlah penderitanya cenderung meningkat dan penyebarannya semakin luas. Penyakit DBD merupakan penyakit menular yang terutama menyerang anak-anak. ${ }^{5}$

Kejadian luar biasa DBD bisa terjadi secara musiman atau berkala di daerah-daerah endemis. Hal ini tampaknya berkaitan dengan banyak faktor, antara lain: yang pertama adalah faktor virologis yaitu virus dengue sebagai agen penyakit. Virus dengue beragam dalam jumlah/distribusinya, serotipe dan virulensinya. Faktor yang kedua adalah manusia sebagai host. Faktor ini dipengaruhi oleh kepadatan populasi, mobilitas, imunitas dan proporsi viremik. Faktor ketiga yang mempengaruhi KLB DBD adalah faktor vektor. Kepadatan dan bionomik nyamuk Aedes spp. sangat berpengaruh dalam KLB DBD. Keempat adalah faktor lingkungan (klimatologis) yaitu ketinggian dari permukaan laut, curah hujan, angin, kelembaban dan musim. ${ }^{6}$

Data WHO tercatat bahwa setiap tahunnya sekitar 500.000 penderita DBD di seluruh dunia, dengan jumlah kematian sekitar 22.000 jiwa. Penderita DBD yang sebelumnya telah terinfeksi salah satu serotipe virus dengue, jika terinfeksi lagi oleh virus dengue serotype yang lain biasanya akan menimbulkan penyakit DBD yang lebih parah, bahkan dapat menimbukan kematian. Di Indonesia jumlah penderita DBD sebanyak 201.885 kasus sedangkan jumlah kasus yang meninggal 1.585 kasus. Di Jawa Timur sebanyak 24.005 kasus penderita DBD dan kematiannya sebanyak 340 kasus. Di Sumatera Utara jumlah penderita DBD tahun 2016 sekitar 8.618 kasus sedangkan jumlah kasus yang meninggal 46 kasus. $^{7}$

Vektor utama penyakit DBD adalah nyamuk Aedes aegypti (di daerah perkotaan) dan Aedes albopictus (di daerah pedesaan) dengan morfologi palpus dan kaki yang mempunyai sisik-sisik putih, skutum (daerah punggung) bergaris putih yang terdapat di bagian tubuh. Nyamuk yang menjadi vektor penyakit DBD adalah nyamuk yang menjadi terinfeksi saat menggigit manusia yang sedang sakit dan viremia (terdapat virus dalam darahnya). Menurut laporan terakhir, virus dapat pula ditularkan secara transovarial dari nyamuk ke telurtelurnya. Virus berkembang dalam tubuh nyamuk selama 8-10 hari terutama dalam kelenjar air liurnya, dan jika nyamuk ini menggigit orang lain maka virus dengue akan dipindahkan bersama air liur nyamuk. Dalam tubuh manusia, virus ini akan berkembang selama 4-6 hari dan orang tersebut akan mengalami sakit demam berdarah dengue. ${ }^{8}$

Tatalaksana DBD fase demam bersifat simtomatik dan suportif yaitu pemberian cairan oral untuk mencegah dehidrasi. Apabila cairan oral tidak dapat diberikan oleh karena tidak mau minum, muntah atau nyeri perut yang berlebihan, maka cairan intravena rumatan perlu diberikan.Antipiretik kadang-kadang diperlukan, tetapi perlu diperhatikan bahwa antipiretik tidak dapat mengurangi lama demam pada DBD. Parasetamol direkomendasikan untuk mempertahankan suhu di bawah $39^{\circ} \mathrm{C}$ dengan dosis 10-15 mg/kgBB/kali. Pasien perlu diberikan minum $50 \mathrm{ml} / \mathrm{kg}$ berat badan dalam 4-6 jam pertama. Setelah keadaan dehidrasi dapat diatasi anak diberikan cairan rumatan $80-100 \mathrm{ml} / \mathrm{kg}$ berat badan dalam 24 jam berikutnya. Kematian akibat DBD adalah $40-50 \%$ dari anak yang mengalami renjatan, tetapi dengan perawatan di ICU maka angka kematian dapat dikurangi menjadi $2 \%$ kadang-kadang tedapat sekuele berupa defek otak akibat dari renjatan dan perdarahan otak. ${ }^{9}$

Tujuan penelitian ini adalah untuk mengetahui distribusi proporsi pasien DBD pada anak berdasarkan umur, jenis kelamin, gejala klinis, diagnosis (pemeriksaan fisik dan pemeriksaan penunjang) di Rumah Sakit Umum Royal Prima 
Medan.

\section{METODE}

Penelitian ini merupakan penelitian deskriptif dengan desain studi kasus. Data yang menjadi populasi dalam penelitian ini adalah seluruh data rekam medis pasien demam berdarah dengue pada anak di Rumah Sakit Umum Royal Prima Medan. Besar sampel sesuai dengan tujuan penelitian untuk mencari proporsi, maka sampel dibutuhkan minimal 100 data rekam medis pasien DBD pada anak. Teknik pengambilan sampel akan dilakukan dengan cara purposive sampling yaitu dipilih rekam medis yang paling lengkap datanya. Karakteristik yang diamati adalah umur, jenis kelamin, gejala klinis (keluhan utama dan keluhan tambahan), pemeriksaan fisik dan pemeriksaan penunjang yang tercatat pada rekam medis pasien demam berdarah dengue pada anak. Data distribusi proporsi dianalisis dan disajikan dalam bentuk tabel.

\section{HASIL DAN PEMBAHASAN}

Hasil penelitian menunjukkan proporsi pasien demam berdarah dengue berdasarkan kelompok umur yang terbanyak adalah 15-19 tahun (29\%). Sedangkan kelompok umur terendah adalah kelompok umur 10-14 tahun (22\%). Proporsi pasien demam berdarah dengue berdasarkan jenis kelamin yang terbanyak adalah laki-laki (59\%), sedangkan jenis kelamin terendah adalah perempuan (41\%).

Tabel 1. Karakteristik umum $(\mathrm{n}=100)$

\begin{tabular}{lll}
\hline Karakteristik & $\mathbf{n}$ & (\%) \\
\hline Umur & & \\
$0-4$ & 25 & 25 \\
$5-9$ & 24 & 24 \\
$10-14$ & 22 & 22 \\
$15-19$ & 29 & 29 \\
Jenis kelamin & & \\
$\quad$ Perempuan & 59 & 59 \\
$\quad$ Laki-laki & 41 & 41 \\
\hline
\end{tabular}

Anak-anak lebih rentan terkena penyakit demam berdarah dengue karena sistem imun yang kurang dibandingkan dengan orang dewasa. Umur merupakan salah satu faktor internal yang berhubungan dengan perilaku seseorang atau masyarakat. Umur berhubungan dengan kegiatan sehari-hari apakah banyak dilakukan di dalam dan di luar rumah, karena banyak nyamuk aedes yang mempunyai kebiasaan menggigit pada pagi dan sore hari, sehingga yang berisiko terkena penyakit demam berdarah dengue (DBD) adalah anak-anak karena mereka lebih banyak melakukan aktifitas di dalam ruangan antara lain di sekolah. Penyakit demam berdarah dengue (DBD) banyak diderita anak-anak karena selang waktu nyamuk menggigit atau mencari darah pada pagi hari di mana anakanak bersekolah, yang mana kemungkinan nyamuk berada di bawah meja belajar, sehingga nyamuk menggigit pada saat anak di ruang kelas. ${ }^{8}$

Semua pasien demam berdarah dengue pada anak mengalami keluhan utama demam tinggi $(100 \%)$. Sedangkan proporsi proporsi pasien demam berdarah dengue berdasarkan keluhan tambahan yang terbanyak adalah mual + muntah + ruam + nyeri kepala $+(23 \%)$ dan yang terendah adalah mual + nyeri kepala + ruam $(2 \%)$.

Tabel 2. Proporsi pasien demam berdarah dengue pada anak berdasarkan keluhan $(n=100)$

\begin{tabular}{lcc}
\hline \multicolumn{1}{c}{ Karakteristik } & $\mathbf{n}$ & $\%$ \\
\hline $\begin{array}{l}\text { Keluhan utama } \\
\text { Demam tinggi }\left(37,5^{\circ} \mathrm{C}-40^{\circ} \mathrm{C}\right.\end{array}$ & 100 & 100 \\
$\begin{array}{l}\text { Keluhan tambahan } \\
\text { Mual + muntah + nyeri kepala }\end{array}$ & 22 & 22 \\
$\quad+$ gusi berdarah & & \\
$\quad$ Nyeri kepala + nyeri otot dan & 8 & 8 \\
$\quad$ sendi + mual & & \\
Mual + nyeri kepala + ruam & 2 & 2 \\
Mual + muntah + ruam + nyeri & 23 & 23 \\
kepala & & \\
$\begin{array}{l}\text { Mual + muntah + nyeri kepala } \\
\text { Muntah + mual + ruam }\end{array}$ & 17 & 17 \\
$\quad$ Muntah + epistaksis + nyeri & 20 & 20 \\
kepala & 8 & 8 \\
\hline
\end{tabular}

Gambaran klinis penderita DBD terdiri dari 3 fase yaitu fase febris, fase kritis, dan fase pemulihan. Fase febris biasanya ditandai demam mendadak tinggi 2-7 hari, disertai muka kemerahan, eritema kulit, nyeri seluruh tubuh, mialgia, artralgia dan sakit kepala. Pada beberapa kasus ditemukan nyeri tenggorok, infeksi faring dan konjungtiva, anoreksia, mual dan muntah. Pada fase ini dapat pula ditemukan tanda perdarahan seperti ptekie, perdarahan mukosa, walaupun jarang dapat pula terjadi perdarahan pervaginam dan perdarahan gastrointestinal. Fase kritis terjadi pada hari 3-7 sakit dan ditandai dengan penurunan suhu tubuh disertai kenaikan permeabilitas kapiler dan timbulnya kebocoran plasma yang biasanya berlangsung selama 24 - 48 jam. Kebocoran plasma sering didahului oleh lekopeni progresif disertai penurunan hitung 
trombosit. Pada fase ini dapat terjadi syok. Bila fase kritis terlewati maka terjadi pengembalian cairan dari ekstravaskuler ke intravaskuler secara perlahan pada 48-72 jam setelahnya. Keadaan umum penderita membaik, nafsu makan pulih kembali, hemodinamik stabil dan diuresis membaik. ${ }^{10}$

Menurut WHO (2011) keluhan tambahan atau gejala penyerta DBD adalah mual + muntah + ruam + nyeri kepala. ${ }^{11}$ Pada penyakit DBD pada umumnya disertai dengan tanda-tanda demam selama 2-7 hari tanpa sebab yang jelas, manifestasi perdarahan dengan tes Rumpel Leede $(+)$, mulai dari petekie (+) sampai perdarahan spontan seperti mimisan, muntah darah, atauberak darah-hitam. Hasil pemeriksaan trombosit menurun (normal:150.000-300.000 $\mu \mathrm{L}$ ), hematokrit meningkat (normal: pria < 45, wanita $<40$ ). Tanda berikutnya akral dingin, gelisah, tidak sadar (DSS, dengue shock syndrome) ${ }^{8}$

Pada distribusi proporsi pasien demam berdarah dengue berdasarkan inspeksi yang terbanyak adalah adanya ruam (40\%) dan yang terendah adalah nyeri otot dan sendi (7\%). Proporsi pasien demam berdarah dengue berdasarkan palpasi pasien semuanya adalah Soepel (100\%). Proporsi pasien demam berdarah dengue berdasarkan perkusi pasien semuanya adalah Timpani (100\%). Hasil pemeriksaan berdasarkan auskultasi pasien semuanya adalah suara paru normal/vesikuler (100\%).

Tabel 3. Proporsi pasien demam berdarah dengue pada anak berdasarkan pemeriksaan fisik $(n=100)$

\begin{tabular}{lcc}
\multicolumn{1}{c}{ Karakteristik } & $\mathbf{n}$ & $\%$ \\
\hline Inspeksi & & \\
$\quad$ Anemia & 8 & 8 \\
$\quad$ Tidak anemia & 14 & 14 \\
$\quad$ Nyeri otot dan sendi & 7 & 7 \\
$\quad$ Epistaksis & 9 & 9 \\
$\quad$ Ruam & 40 & 40 \\
$\quad$ Gusi berdarah & 22 & 22 \\
$\begin{array}{l}\text { Palpasi } \\
\quad \text { Soepel }\end{array}$ & 100 & 100 \\
$\begin{array}{l}\text { Perkusi } \\
\quad \text { Timpani }\end{array}$ & 100 & 100 \\
$\begin{array}{l}\text { Auskultasi } \\
\quad \text { Suara paru normal/vesikuler }\end{array}$ & 100 & 100 \\
\hline$\quad$
\end{tabular}

Secara teori pemeriksaan fisik pada pasien DBD yaitu manifestasi perdarahan, uji bendung positif ( $\geq 10$ petekie/inch ${ }^{2}$ ) merupakan manifestasi perdarahan yang paling banyak pada fase demam awal, mudah lebam dan berdarah pada daerah tusukan untuk jalur vena, petekie pada ekstremitas, ketiak, muka, palatum lunak serta epistaksis, perdarahan gusi. Pemeriksaan fisik pada palpasi didapatkan hepatomegali teraba 2-4 $\mathrm{cm}$ di bawah arcus costae kanan dan kelainan fungsi hati (transminase) lebih sering ditemukan pada DBD. Berbeda dengan DD, pada DBD terdapat hemostasis yang tidak normal, perembesan plasma (khususnya pada rongga pleura dan ronggal peritoneal), hipovolemia, dan syok, karena terjadi peningkatan permeabilitas kapiler. Perembesan plasma yang mengakibatkan ekstravasasi cairan ke dalam rongga pleura dan rongga peritoneal terjadi selama 24-48 jam. $^{12}$ pemeriksaan perkusi pada abdomen penyakit DBD yaitu timpani, region kuadran kanan atas pekak, shifting dullness negatif. Sedangkan pada pemeriksaan auskultasi pada paru penyakit DBD yaitu suara nafas vesikuler, ronki negatif, wheezing negative. ${ }^{8}$

Tabel 4. Proporsi pasien demam berdarah dengue pada anak berdasarkan pemeriksaan penunjang $(n=100)$

\begin{tabular}{lcc}
\hline \multicolumn{1}{c}{ Karakteristik } & $\mathbf{n}$ & $\%$ \\
\hline Uji Tourniquet & & \\
$\quad$ Positif & 56 & 56 \\
$\quad$ Negatif & 44 & 44 \\
$\begin{array}{l}\text { Pemeriksaan Hemoglobin } \\
\quad \text { Normal (11-14 gr/dl) }\end{array}$ & 89 & 89 \\
$\quad$ Tidak normal & 11 & 11 \\
$\begin{array}{l}\text { Pemeriksaan Hematokrit } \\
\quad \text { Normal (33-38\%) }\end{array}$ & 89 & 89 \\
$\quad$ Tidak normal & 11 & 11 \\
$\begin{array}{l}\text { Pmeriksaan Leukosit } \\
\quad \text { Normal (9000-12000/mm3) }\end{array}$ & 11 & 11 \\
$\quad$ Tidak normal & 89 & 89 \\
$\begin{array}{l}\text { Pemeriksaan Trombosit } \\
\quad \text { Trombositopenia } \\
\quad(<100.000 / \text { mm3) }\end{array}$ & 100 & 100 \\
\hline
\end{tabular}

Pada tabel 4 terlihat distribusi proporsi pasien demam berdarah dengue berdasarkan uji tourniquet yang terbanyak adalah positif (56\%). Sedangkan pada pemeriksaan hemoglobin yang terbanyak adalah normal (89\%). Proporsi pasien demam berdarah dengue berdasarkan pemeriksaan hematokrit yang terbanyak adalah normal (89\%). Pada hasil pemeriksaan leukosit yang terbanyak adalah tidak normal $(11 \%)$.

Tes tourniquet positif $(\geq 10$ petekie/inchi persegi) merupakan fenomena perdarahan yang sering dijumpai pada awal fase demam. Manifestasi perdarahan pada DBD yaitu Uji 
Tourniquet atau uji bendung (+). Hemaktokrit dijumpai pada fase demam awal. Sedikit peningkatan karena demam tinggi, anoreksia dan muntah. Kenaikan mendadak hematokrit di amati secara bersamaan atau segera setelah penurunan jumlah trombosit. Sedangkan jumlah leukosit biasanya normal pada awal demam, kemudian leukopenia terjadi dengan menurunnya neutrofil dan berlangsung selama periode demam. jumlah trombosit biasanya normal demikian pula kompenen lain dari sistem koagulasi. Trombositopenia ringan sering terjadi sekitar setengah dari pasien DBD akan mengalami penurunan trombosit hingga di bawah 100 ribu $\mathrm{sel} / \mathrm{mm}^{3}$. Namun trombositopenia berat di bawah $50 \mathrm{ribu}$ sel $/ \mathrm{mm}^{3}$ jarang terjadi. ${ }^{13}$

\section{KESIMPULAN}

Penelitian ini menyimpulkan pasien DBD anak terbanyak pada kelompok umur 15-19 tahun $(29 \%)$ dan berdasarkan jenis kelamin yang terbanyak laki-laki (59\%). Keluhan utama semua pasien adalah demam tinggi dan keluhan tambahan paling banyak adalah mual + muntah + ruam + nyeri kepala $+(23 \%)$. Hasil pemeriksaan fisik menunjukkan pasien yang diinspeksi terbanyak mengalami ruam (40\%). Pada pemeriksaan palpasi, perkusi, dan auskultasi menunjukkan semua pasien memiliki gejala soepel, timpani, dan suara paru normal/vesikuler.

Berdasarkan uji Tourniquet yang terbanyak adalah positif, pemeriksaan hemoglobin yang terbanyak adalah normal (89\%), pemeriksaan hematokrit yang terbanyak adalah tidak normal (89\%) dan pemeriksaan leukosit yang terbanyak adalah tidak normal (89\%). Pada pemeriksaan trombosit menunjukkan semua pasien mengalami trombositopenia.

\section{REFERENSI}

1. Malavige GN, Fernando S, Fernando DJ, Seneviratne SL. 2004. Dengue viral infections. Postgrad Med J. 80(948):588-601. doi:10.1136/pgmj.2004.019638

2. Sorisi AMH. 2013. Transmisi transovarial virus dengue pada nyamuk aedes Spp. Jurnal Biomedik 5(1): 26-31

3. Bhatt, S., Gething, P. W., Brady, O. J., Messina, J. P., Farlow, A. W., Moyes, C. L., Drake, J. M., Brownstein, J. S., Hoen, A. G., Sankoh, O., Myers, M. F., George, D. B.,
Jaenisch, T., Wint, G. R., Simmons, C. P., Scott, T. W., Farrar, J. J., \& Hay, S. I. 2013. The global distribution and burden of dengue. Nature, 496(7446), 504-507. https://doi.org/10.1038/nature12060

4. Kusriastuti R. 2005. Epidemiologi Penyakit Demam Berdarah Dengue dan Kebijaksanaan Penanggulangannya di Indonesia. Seminar Dengue Control Up-date. Yogyakarta: Pusat Kedokteran Universitas Gajah Mada.

5. Prasetyowati H, Astuti EP. 2010. Serotipe Virus Dengue di Tiga Kabupaten/Kota Dengan Tingkat Endemisitas DBD Berbeda di Propinsi Jawa Barat. Aspirator Vol. 2 No. 2: $120-124$

6. Mardihusodo SY. 2005. Cara Inovatif Surveilans \& Pengendalian Vektor DBD. Dalam Seminar Kedokteran Tropis Kajian KLB DBD dari Biologi Molekuler sampai Pemperantasannya. Pusat Kedokteran Tropis, Fakultas Kedokteran, Universitas Gadjah Mada, Yogyakarta.

7. Kementerian Kesehatan. 2018. Situasi Penyakit Demam Berdarah di Indonesia Tahun 2017. Pusat Data dan Informasi Kementerian Kesehatan. Jakarta

8. Widoyono. 2011. Penyakit Tropis: Epidemiologi, Penularan, Pencegahan, dan Pemberantasannya. Jakarta: Erlangga

9. Hadinegoro SR, Kadim M, Devaera $Y$, Idris NS, Ambarsari CG. 2012. Update Management of Infectious Diseases and Gastrointestinal Disorders. Departemen IImu Kesehatan Anak Fakultas Kedokteran Universitas Indonesia

10. Kementerian Kesehatan. 2010. Jendela Epidemiologi Demam Berdarah Dengue Vol.2. Jakarta

11. World Health Organization. 2011. Comprehensive Guidelines for Prevention and Control of Dengue and Dengue haemorrhagic Fever

12. Karyanti Rahma Mulya. 2013. Diagnosa dan Tatalaksana Terkini Dengue. FK UI

13. Ginting F, Ginting J, Kembaren T, Rahimi A, Sembiring E, Saragih R, Ginting GMJ. 2017. Pedoman Diagnostik dan Tatalaksana Infeksi Dengue dan Demam Berdarah Dengue Menurut Pedoman WHO 2011. Universitas Sumatera Utara 